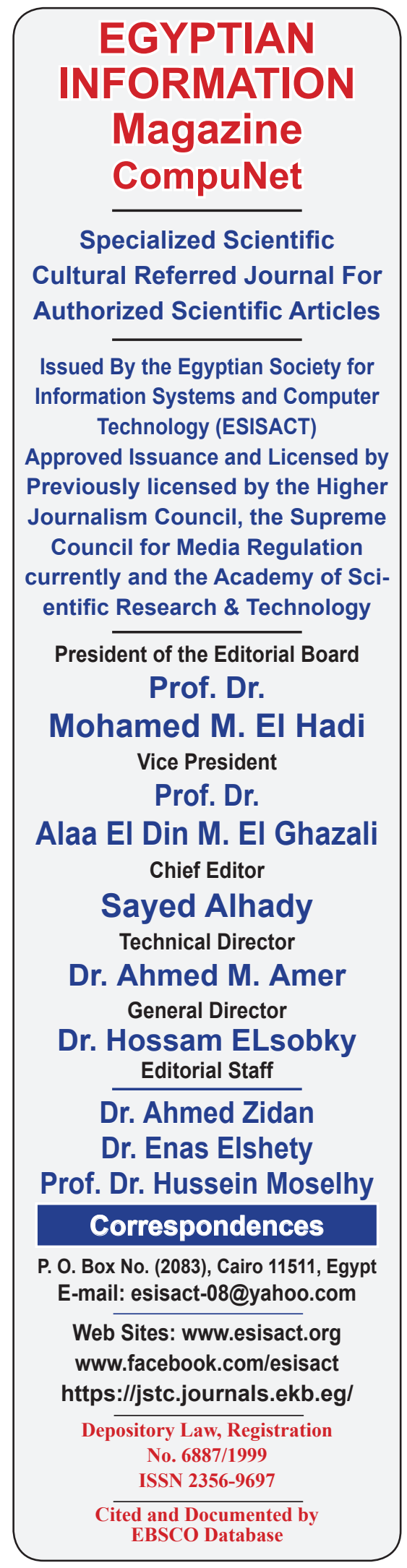

\title{
Scientific Consultative Committee Members
}

Prof. Dr. Abdelbadeeh M. Salem

Prof. Emeritus of Computer Science, Faulty of Computers and Information, Ain Shams University

Prof. Dr. Abdellatif Elgazzar

Prof. emeritus of Educational Technology, Girls College, Ain Shams University

Prof. D. Alaa El-Din M. El Ghazali

Prof. of Information Systems and Former President of Sadat Academy for Management Sciences Prof. Dr. Gamal M. Aly

Prof. of Software Engineering, Faculty of Engineering, Ain Shams University

Prof. Dr. Magdy H. Abouella

Prof. Emeritus of Computer Science, Sadat Academy Vice Former President

\section{Prof. Dr. Mohamed Abdelhameed Ahmed}

Prof. Emeritus of Educational Technology, Faculty of Education, Helwan University

\section{Prof. Dr. Mohamed Fahmi Tolba}

Prof. Emeritus of Computer Science, Faculty of Computers and Information, Ain Shams University, Former President of Scientists Syndicate

Prof. Dr. Mohamed Fathy Abdelhady

Prof. Emeritus of Library and Information Science, Faculty of Arts, Cairo University

Prof. Dr. Mohamed Magdy Kabeil

Prof. Emeritus of Computer Science, Sadat Academy for Management Silences

Prof. Dr. Mohamed M. El Hadi

Prof. Emeritus of Information Systems, Sadat Academy for Management Sciences

Prof. Dr. Nashaat El Khamisy Mohamed Prof. Emeritus of Computer and Information Systems, Sadat Academy

Prof. Dr Nevine Makram Labib

Prof. and Head of the Department of Computer and Information

Systems, Sadat Academy for Management Sciences

Prof. Dr. Safaa Sayed Mahmoud

Prof. of Information Technology in Education, Faculty of Specified

Faculty of Specified Education, Ain Shams University

Prof. Dr. Sherif Kamel Shahin

Prof. of Library and Information Science and

Dean of the Faculty of Arts, Cairo University 